\title{
The Impact of Suburbanisation on Power Relations in Settlements of Budapest Agglomeration
}

\author{
Márton BagyuraA \\ Received: June 11, 2019 | Revised: August 17, 2019 | Accepted: October 03, 2019 \\ doi: 10.5937/gp24-22092
}

\begin{abstract}
The aim of the current paper is to help to understand the transformation of suburban areas in Central Eastern European metropolitan regions with regard to the power relations. The study area is Budapest Agglomeration, which has experienced significant social, economic, and environmental changes after the collapse of state socialist regimes due to the intense suburbanisation. This study examines the composition of municipal councils in Budapest Agglomeration and tests the hypothesis that during the suburbanisation, the newcomers seize the political power in the suburbs. The analysis based on a database about municipal councils members of 18 settlements, and there are data about the main socio-demographic characteristics of these settlements. The results show the growing number of settlements where the incomers become dominant in municipal councils. The role of socio-demographic factors in this process is interesting as cannot be proved a clear relationship between these factors and the changes in municipal councils.
\end{abstract}

Keywords: Budapest Agglomeration; suburbanisation; power relations; municipal council

\section{Introduction}

Central and Eastern European (CEE) countries have gone through a significant transformation after the collapse of the state socialist regimes. The spontaneous socio-spatial processes could become intense after the post-socialist transition because these were restricted by the state before. Common features were in these countries the privatization of public housing and agriculture land, liberalization of the housing market, increasing income, and evolve of the new local governance system. Socio-economic transformation comes along with intensive suburbanisation in the Post-Socialist region. This process has been an essential urban phenomenon in the last three decades, which has determined the development of metropolitan areas and the spatial distribution of society. The population growth was more intensive in the suburban areas than in the cities, and the suburbs undergone previously rarely experienced development in infrastructure and services, even though this development was not always able to keep up with the needs, which came with the new and growing population. The newcomers forced several kinds of development out, and new enterprises settled in the agglomeration and participated in the improvements. It was an unplanned development and uneven in space, namely there are better and worse developing settlements. In addition, the spatial pattern of social strata changed in the urban areas. The middle class moved to the surroundings settlements, but in CEE, unlike the western suburbanisation, lowstatus people also decided to leave the city in order to decrease their housing costs (Brade et al., 2009;

\footnotetext{
A Centre for Social Sciences - HAS Centre of Excellence, H-1097 Budapest, Tóth Kálmán u. 4. bagyura.marton@tk.mta.hu
} 
Sailer-Fliege, 1999; Szelényi, 1996; Stanilov \& Sýkora, 2014a, 2014b, 2014c).

In most respects, social consequences and characteristics of suburbanisation have been the same in Budapest Agglomeration as in the other post-socialist metropolitan areas. In connection with the local communities important result of migration from the city to the suburbs is the evolve of high-status spaces in the suburban zone and even within its settlements (Csanádi et al., 2010) as previous studies presented similar processes in CEE metropolitan regions (e.g. Kährik \& Tammaru, 2008; Krisjane \& Berzins, 2012; Ourednícek, 2007). Western urban studies (e.g. Scicchitano \& Johnson, 2012; Ross, 2014) presented that in suburban areas newcomers from upper-middle-class try to influence the decisions of municipal councils in order to serve the newcomers' interests the development of their settlements. The so-called 'not in my backyard' phenomenon is a striking example of how the new population can influence the further development of settlements. Similarly, in Budapest Agglomeration has appeared the conflicts between the newcomers and the former residents because newcomers' interests often contrasted with the former residents' interests. Although in the Budapest Agglomeration the presence of the highly well-off population is less common than in Western metropolitan region, it is rather the home of the middle-class and upper-middle-class. Nevertheless, the differences in lifestyle between the new and old populations are manifested here in various conflicts (Csanádi et al., 2010; Váradi, 1999). The conflicts can express in the local policy and at this point become important the question who has the ability to enforce interest and how does it happen.

Although momentous suburbanisation in Budapest Agglomeration started three decades ago, except for the exemplary description of the activity of local civil movements, has not been examined the change of power relations in the suburbs systematically. The aim of this paper to contribute to the understanding of the social consequences of suburbanisation on the local community, concerning power relations. Is it a rather complex subject; in this current study, I deal with the representation of the new population in municipal councils. In Hungary, municipal councils decide on the way of local public service development, the local tax rate, and the settlement structure. In recent years the role of the councils has changed and declined significantly in several fields but still play a very important role in many cases. It is widely accepted that people who moved out of Budapest want to participate in decision-making about their settlements. It may be presumed that there is a clear relationship between the population growth in suburbs and the proportion of new residents in the municipal councils. This concept, however, hardly examined empirically. In this paper, I test this statement based on data collected from councillors of 18 settlements and answer the following questions.

How has the proportion of people who moved out of Budapest changed in municipal councils of suburbs over the last three decades?

How can socio-demographic characteristics explain the differences in the composition of municipal councils among various settlements?

\section{Suburbanisation in Budapest Agglomeration}

Budapest agglomeration is a statistical zone inside the metropolitan area. Delineation of the agglomeration is based on commuting relations and corresponds to the administrative boundaries in the agglomeration zone. Agglomeration includes settlements located near to Budapest and have experienced the suburbanisation since the post-socialist transition; thus, in this paper, this spatial unit is suitable to use for analysing a long-term process.

In Budapest Agglomeration, suburbanisation accelerated after the collapse of the socialist regime in 1989/90. The population of Budapest decreased by $14.3 \%$ between 1990 and 2011 (from 2.017 to 1.73 million) while the people of the agglomeration increased by $38.8 \%$ in this period (from 448 to 622 thousand) (HCSO, 1990, 2011). According to the available statistical data, the entire area of the agglomeration has been involved in suburbanisation since the 1990s (HCSO, 2001, 2011). At the end of the 20oos, the population growth slowed down in the agglomeration, mostly due to the global financial crisis, decreasing mortgage subsidies, and urban renewal projects in Budapest's inner city (Kovács \& Tosics, 2014).

Municipal councils in agglomeration have played an important role in the process of suburbanisation. In the early 1990s, it was typical that they supported the population growth and tried to make attractive the residential area because they expected an increase in revenue of settlements, mainly by the taxes (Szirmai et al., 2011; Tosics, 2006; Kovács, 1999). Later, because of the changing tax system and consequently decreasing revenue, the leadership of the settlements could not provide the proper services and infrastructure for the local population and therefore, they changed their policy. The aim of this new policy was obstructing the population growth or finding a way to reduce the adverse effects of the process (Szabó, 2003; Gergely, 2014). 
Effects of suburbanisation on Budapest Agglomeration have been examined in many aspects. Various form of economic activity appeared and workplaces have been created, although the increasing car use and commuting between home and the workplace has several harmful impacts on the environment and health condition (Kondor, 2016; Kovács et al., 2019; Váradi, 2014). Mainly but not exclusively due to the high number of workplaces, there are important cooperation and interdependence between settlements, and as a result of this, the area has become more polycentric (Kovács et al., 2014). Because of the various transformation, this area has to face administrative and regional planning problems (Somlyódyné Pfeil, 2011).

In terms of society, the most significant consequence of suburbanisation is the change of socio-spatial disparities and segregation patterns. The essential trend was observed that in Budapest metropolitan area from the inner part of the city to the suburban zone border, the proportion of high-status residents decrease. However, this trend is not entirely general because on the one hand there are parts of the suburban area where the high-status population lives and on the other hand the parts of the agglomeration and settlements are also fragmented. (Szirmai, 2011, 2016; Csanádi et al., 2010; Szirmai 2019).

Social fragmentation of the Budapest Agglomeration is not a new phenomenon, but it was strengthened and modified by the suburbanisation. Financial opportunities always had a dominant role in spatial mobility. Those who could take advantage of the post-socialist transition, for instance, who could buy a good and cheap dwelling during the privatization and who was in the best financial situation could move from Budapest to the much-valued parts of the area already in the 1990s (Western and Northwestern sectors of Agglomeration, Figure 1.) (Csanádi \& Csizmady, 2002). These settlements conserved, moreover raised their high-status. The other parts of agglomeration have become socially fragmented by high-status and low-status settlements, by the waves of suburban- isation, which have strengthened the socio-spatial differences (Csanádi et al., 2010; Váradi \& Szirmai, 2012).

In addition to the financial condition, several factors influenced the choice of a new residence, such as the desire for a detached house, better housing condition than in the city, rural lifestyle, silence, tranquillity, green area and not least the role of the residence in the individuals' social status (Beluszky, 1999; Tímár, 1999; Dövényi \& Kovács, 1999, Csanádi et al., 2010). Consequently, people who have moved out of Budapest to the suburbs had different concepts and demands about the new residence and its population and used the settlement in different ways (Csurgó \& Csizmady, 2012). Csurgó (2013) defined two main type of people who have moved out of Budapest to the agglomeration by their concept about the rural life: the suburban way of life - people homes are in the suburb, but their life primarily be attached to the city; retraditionalization - people actually live in the suburb, they are part of local community; however, this is also not the way of traditional rural life (with farming). And there is a third type which is the combination of the former two - the city still is important in their life, and at the same time they integrate into the local community. Diverse lifestyles and interests led to conflicts between the original residents and the newcomers. These conflicts usually focused on the function and transformation of the settlements (Váradi, 1999; Szirmai, 2011b; Szirmai \& Váradi, 2012; Csurgó, 2013).

As a result of these conflicts, residents established local civic organisations to try to influence the local policy (Váradi, 1999) since the most conflicts were related to the impacts of suburbanisation or to issues within the competence of municipal councils which determine the way of life of residents (Csurgó \& Csizmady, 2012; Szabó, 2003; Váradi, 1999).

From the literature, it emerges that to understand the transformation of suburbs, we have to make profound research about the power relations, including the participation of different population groups in municipal councils.

\section{Study Area and Database}

Budapest Agglomeration (Figure 1) includes 38 towns and 43 villages with different population size. To answer the research questions, I examine settlements where the population was less than 10 thousand in 2011 at the year of the last census. According to field research experiences, personal relations and acquaintance has a more significant impact on power relations and local policy in small settlements than in larger ones. The filtered sample includes 18 settlements, which has been selected from all the six sectors of the agglomeration.
To determine the proportion of incomers - it means people who moved out of Budapest - in municipal councils, I collected data about the former residence of councillors. In the absence of an official database about personal particulars of councillors, the information comes from many sources: websites, leaflets, interviews (from media), newspapers, local history books, etc. There was not a specified way of the data collection like questionnaire or interviews have not made for this research. I used more than one hun- 


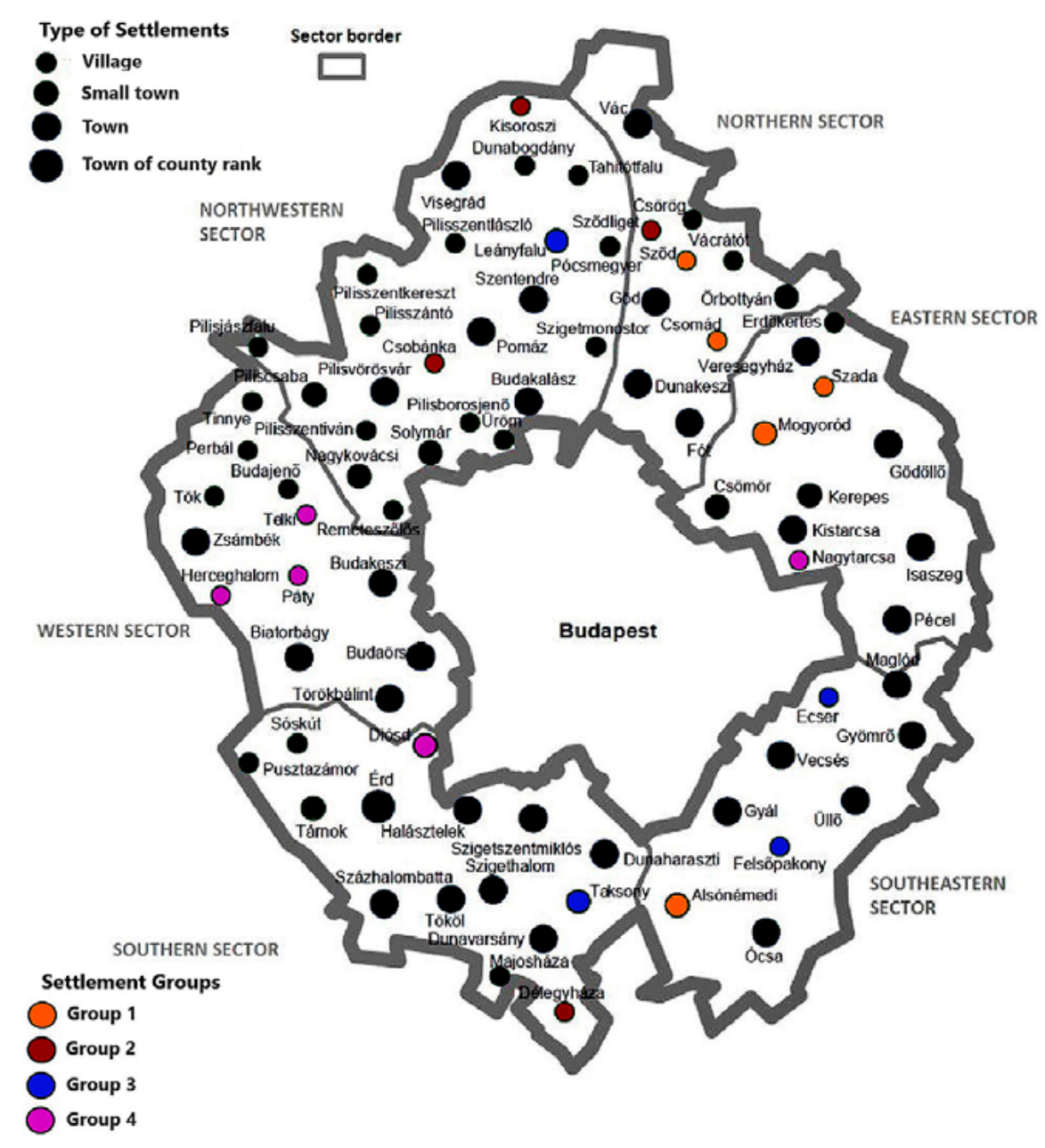

Figure 1. Budapest Agglomeration Source: HCSO, 2011

dred sources (mostly from the internet) to collect data about the 1060 councillors of the 18 settlements.

I divided the councillors into three groups: the first one includes people who moved out of Budapest to the suburbs, the second one includes people who were born and lived in the suburbs (henceforth abbreviated original residents). There is a third group of councillors, who moved in the suburban zone from rural settlements. However, their weight in the councils has not been significant, and the rural spatial mobility is quite a different process from suburbanisation, thus in the current paper, I do not deal with this group.

In Hungary, from 1990 to 2014 municipal council elections were held every four years. The number of councillors in each settlement depends on the population size. In order to typify the settlements accord- ing to the change of councillor composition and these types can be comparable by socio-demographic characters, it was necessary that the number of councillors be the same. Otherwise, the larger settlements with more councillors could distort the results. Thus, data used in this analysis are weighted; as a result of this, all settlements have the same number of councillors in each period.

Missing data are lower than 20 percent and does not affect the results.

Statistical data used in the analysis has been taken from censuses except for data about the personal income tax. Census data are the most reliable and in the case of proportion of graduates is the only available. Censuses were held in 1990, 2001 and 2011. The other source is the municipal database of Hungarian Information System of Regional Development (TEIR). 


\section{Results}

\section{Incomers in municipal councils}

In the studied area, the number of settlements has been growing, where the incomers have dominance in municipal council (Table 1.). This is a slow process, and the incomers outnumbered the other population groups in councils only in one-third of the settlements even at the end of the examined period. Nevertheless, data predict the direction of change. The number of settlements where original residents dominate decreased until 2014, by the time remained only seven out of 18 . This is mainly due to the presence of people who moved to this area from rural settlements. In most cases, this group is not significant in councils, but their presence enough for neither the original residents nor the incomers get the majority in the councils. And there are settlements where the original residents and incomers have a similar proportion in councils - because of the missing data is undecidable which group is dominant. In this paper, I examine the settlements based on only the proportion of settlements is similar in each group: the first and the fourth group includes five, and the other two include four settlements. The spatial location of the settlements is not completely the same as the categorization used in this study. It also indicates distinct changes in the greater part of agglomeration as previous studies presented it, for instance, in terms of social characteristics (Csanádi et al., 2010).

Figure 2. shows the exact proportions of incomers in every group. It can be seen, that the first and the fourth group differs the most from the others. In the first group, not only the percent is low every year, but there is no rising tendency either. In contrast, in the fourth group, incomers' proportion is steadily increasing.

In the further analyses, I compare these four settlement groups based on their main socio-demographic characteristics which are in connections of the suburbanisation such as population size, the proportion of graduates and newly built dwellings, and financial

Table 1. Composition of municipal councils

\begin{tabular}{|l|c|c|c|c|c|c|}
\hline The majority of municipal council... & \multicolumn{5}{|c|}{ Election year } \\
\cline { 2 - 7 } & 1994 & 1998 & 2002 & 2006 & 2010 & 2014 \\
\hline ...are original residents. & 13 & 13 & 11 & 9 & 8 & 7 \\
\hline ...are in-moving people. & 2 & 3 & 4 & 5 & 7 & 10 \\
\hline ...are people who moved out of Budapest. & 0 & 1 & 1 & 3 & 3 & 6 \\
\hline Similar percent of original local people and who moved out of Budapest. & 3 & 2 & 3 & 4 & 3 & 1 \\
\hline Total & 18 & 18 & 18 & 18 & 18 & 18 \\
\hline
\end{tabular}

Source: Edited by the author based on the own database

Table 2. Settlement groups based on the proportion of incomers in municipal councils

\begin{tabular}{|l|l|l|}
\hline Settlement groups & The proportion of incomers in municipal councils... & Settlements \\
\hline 1st group & $\ldots$ was lower than $20 \%$ in every year. & $\begin{array}{l}\text { Alsónémedi, Csomád, } \\
\text { Mogyoród, Szada, Sződ, }\end{array}$ \\
\hline 2nd group & $\begin{array}{l}\text {.. has increased slowly and the incomers have never been a significant } \\
\text { group. }\end{array}$ & $\begin{array}{l}\text { Csobánka, Délegyháza, } \\
\text { Kisoroszi, Sződliget }\end{array}$ \\
\hline 3th group & $\begin{array}{l}\text {..was relatively high in } 1994 \text { and it has increased significantly from } \\
2010 .\end{array}$ & $\begin{array}{l}\text { Ecser, Felsőpakony, } \\
\text { Leányfalu, Taksony }\end{array}$ \\
\hline 4th group & $\begin{array}{l}\text {..increased constantly from 1994 to 2014 and the incomers had } \\
\text { outnumbered the other population groups in every settlement in 2014. }\end{array}$ & $\begin{array}{l}\text { Diósd, Herceghalom, } \\
\text { Nagytarcsa, Páty, Telki }\end{array}$ \\
\hline
\end{tabular}

Source: Edited by the author based on the own database

incomers in municipal councils without considering the different presence of original residents and people who moved from rural settlements.

The proportion of incomers are various in municipal councils but can be described four types of settlements based on their proportion in each year of election and the trend of change (Table 2.). The number of situation. Thereby we can understand the relation between the change of municipal councils and the migration. The following figures show the average values of the groups to prevent the effects derive from different size of settlements. First, will be presented in detail the difference between the four settlement groups by the main socio-demographic factors and then Fig- 


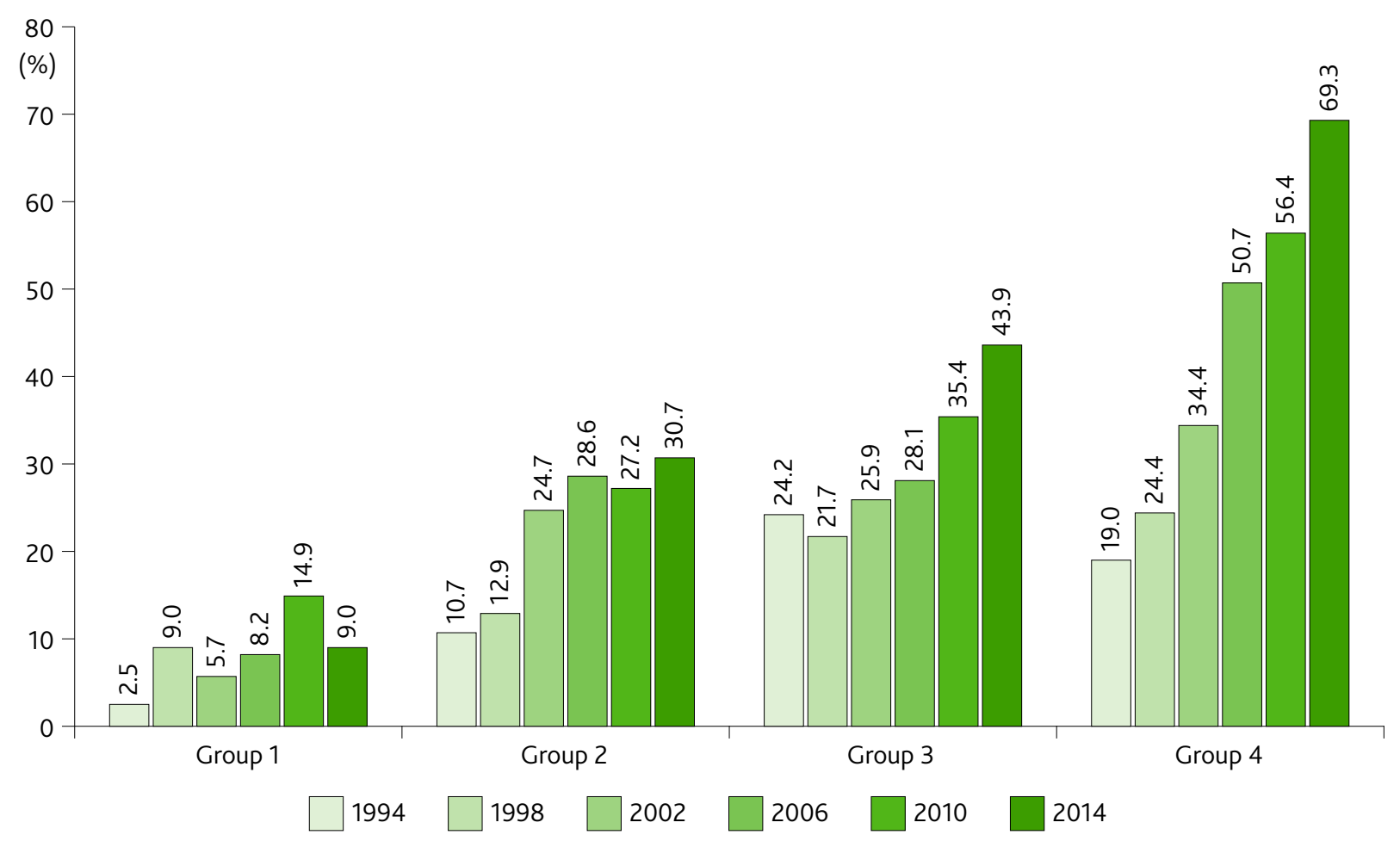

Figure 2. The proportion of incomers in municipal councils by settlements groups (\%) Source: Edited by the author based on the own database

ure 7. shows summing the difference between the settlement groups by these factors.

\section{The main social-demographic characteristics of settlement groups}

Data show a significant relationship between population growth and the proportion of incomers in municipal councils. However, difficult to interpret this relationship because it does not prove a linear correlation, such as the more intense population growth, the more incomers are in councils. The population growth rate was the highest in the fourth settlement group in the 1990 s and also in the 200os, as the proportion of the incomer council members. In contrast, the population growth in the first group was also significant in the 20oos, but this did not result in the growing proportion of incomer council members. The third group did not experience substantial population growth between 1990 and 2001, and still, has grown the proportion of incomers in the municipal councils.

Based on the foregoing, it can be said that the population growth itself does not explain the differences

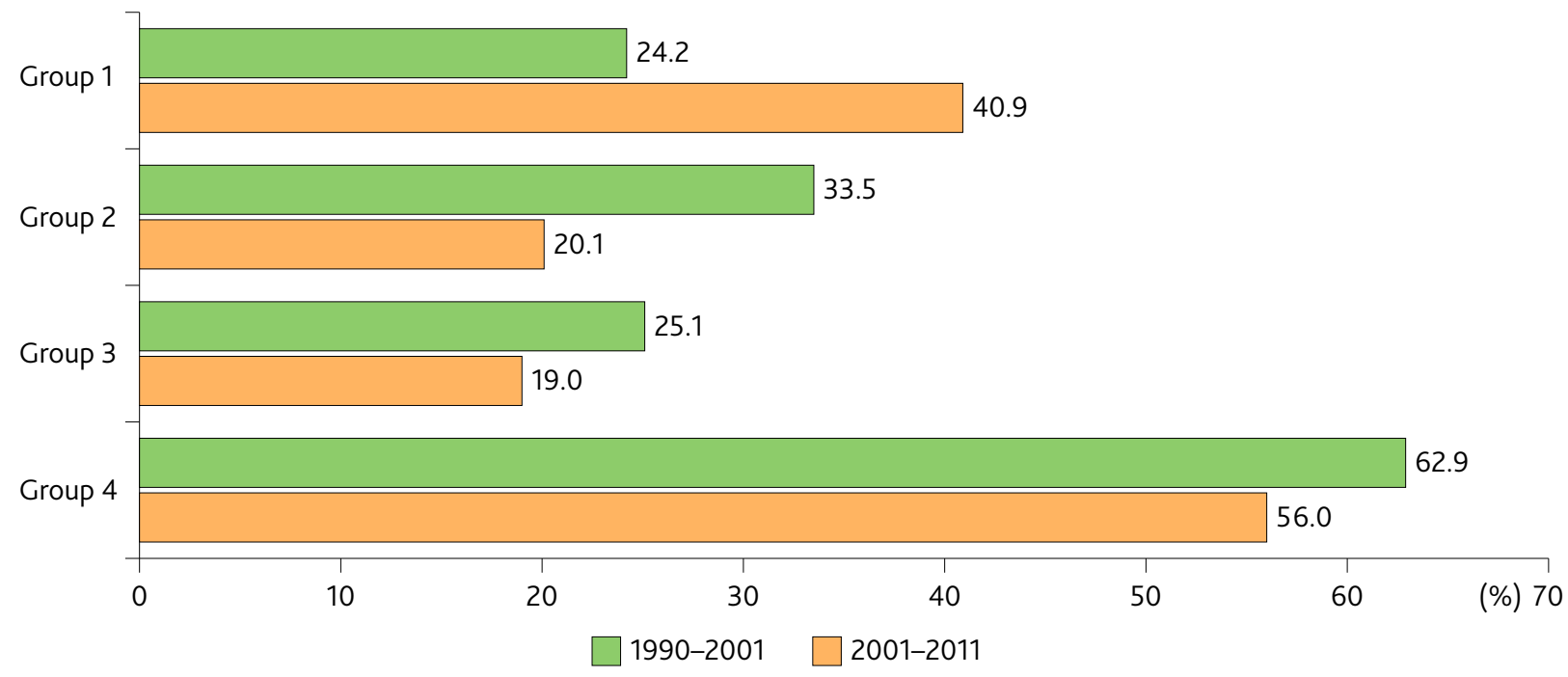

Figure 3. The average population growth by settlements groups (\%) Source: Edited by the author based on censuses 


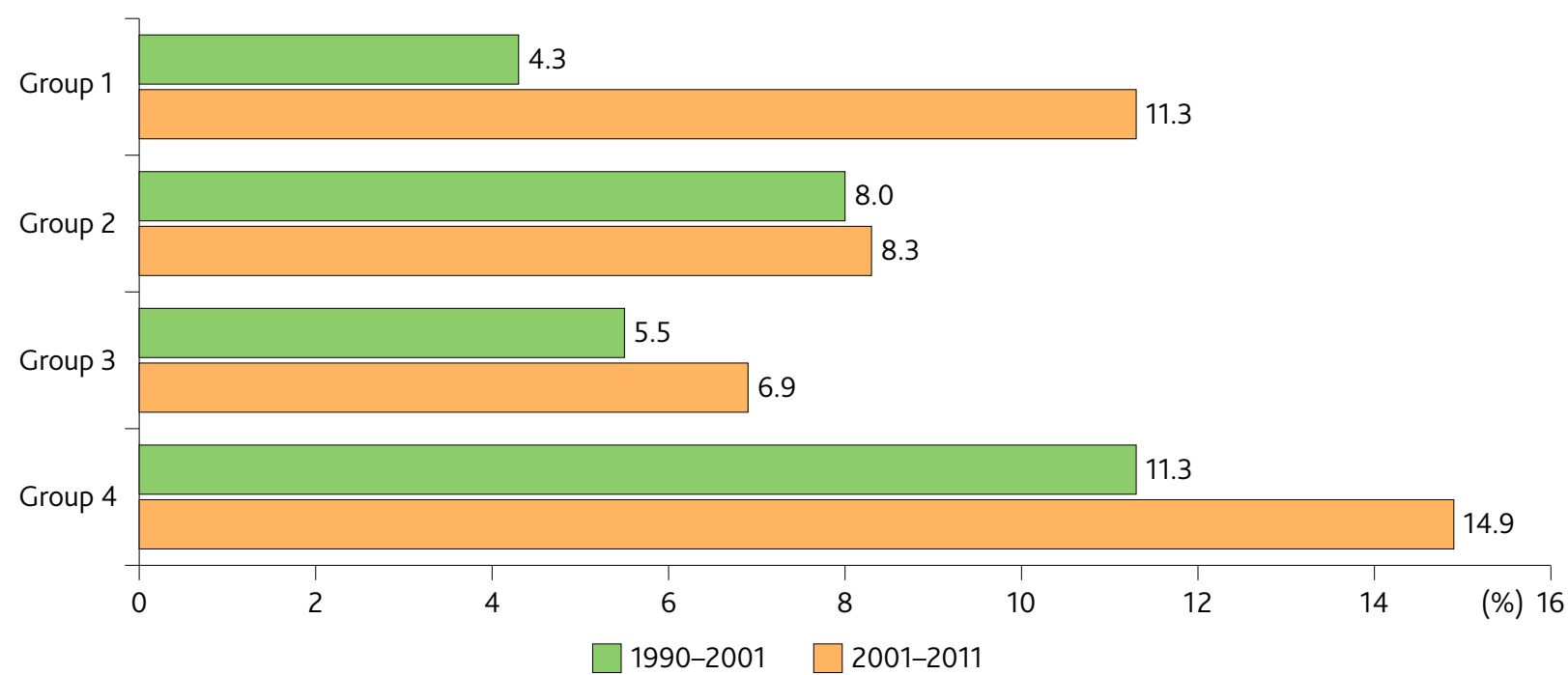

Figure 4. The average growth of graduates (percentage points) among 25 years old and older population Source: Edited by the author based on censuses

in the composition of municipal councils. The previous research referred before, pointed out that suburbanisation has been spatially an unequal process, and evolved low-status and high-status settlements in the agglomeration. Therefore, we need to examine the differences between the groups based on three social status indicator.

As predicted, the rate of growth of graduates (among 25 years old and older population) was the highest in the fourth group between the time of the three censuses, and graduates' proportion was also the highest in this group. Despite the different proportion of incomers in councils, the second and the third groups do not differ from each other significantly, neither according to the rate of graduates nor according to the change, not once. In the settlements of the first group, the proportion growth of graduates was the smallest in the first period, and it was high in the second period. It implies that a lot of graduates (also by number) moved in these settlements. However, in spite of the population growth and especially the increase in the rate of graduates, incomers could not take over the dominance in municipal councils.

The financial situation is measured with the personal income tax per taxpayer. The first data are available from 1992. In Hungary, the personal income tax system has gone through many significant changes in the past three decades; thus, there can be a large difference between two consecutive years by the exact values of tax per taxpayer regardless the changes in income. Therefore Figure 5 . shows the deviation the change of the tax per taxpayer by settlement groups

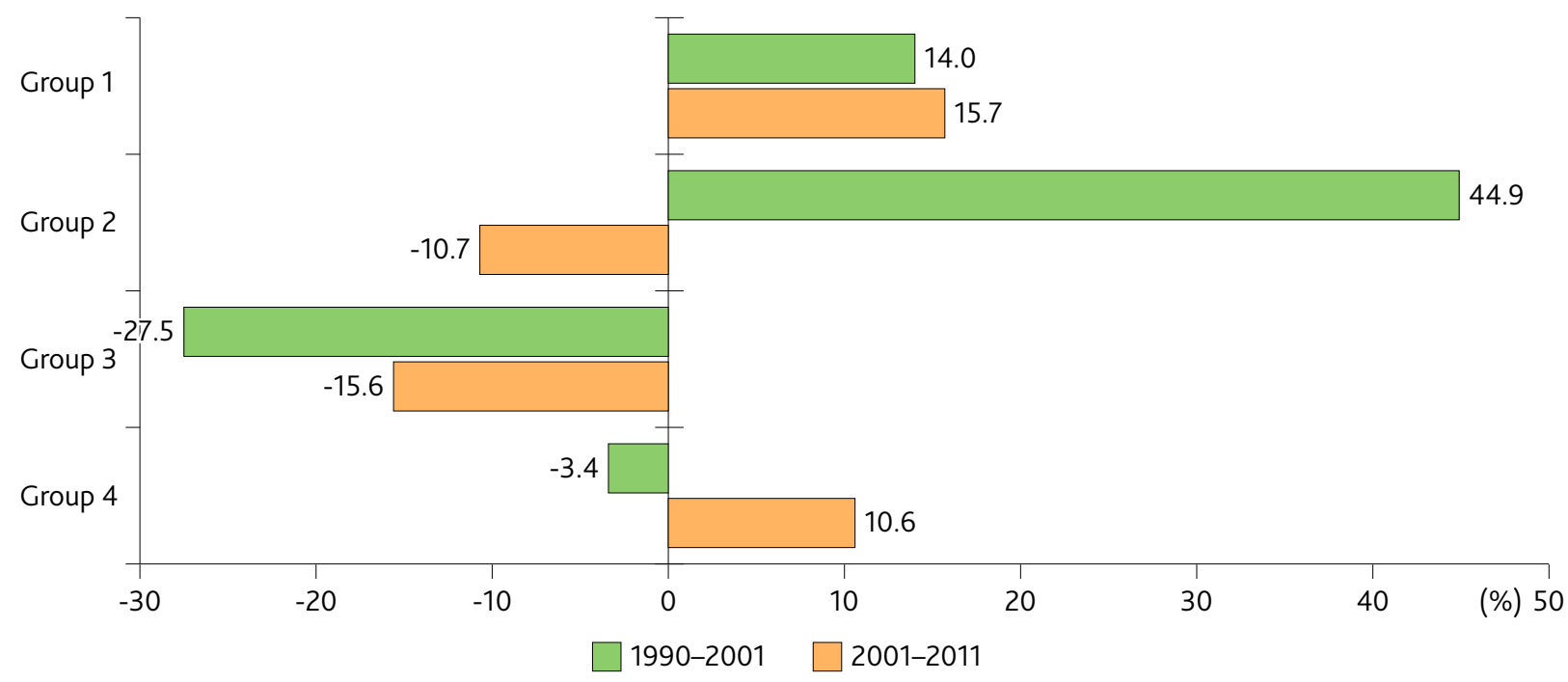

Figure 5. Deviation the change of the tax per taxpayer by settlement groups from the average change of the 18 settlements (\%)

Source: Edited by the author based on TEIR database 
from the average change of the 18 settlements. The tax per taxpayer increased in every settlement; on the figure, the positive values mean growth above average, the negative values means growth under average.

In the first period, the differences between settlement groups were much larger than in the second period, and they typically do not follow the change in the proportion of incomer council members. Although the first group is the only one with positive change (i.e. above-average) in both periods, the proportion of incomers remained low. The third group is just the opposite, the only one where change has always been below average, and yet there has been an increase in the proportion of incomer councillors. However, when interpreting the figure, it is important to note that it shows the change and not the financial situation of those living in each settlement group. In the fourth group, tax per taxpayer growth was below average in the first period and just second after 2001, but
Figure 7. shows the above-used variables standardized and shows the deviation from the average values of the 18 settlements by periods. In the case of annual tax per taxpayer, I use data from 1992 and not from 1990. On the previous figures can be seen the exact values of socio-demographic variables of the settlement groups (except in the case of tax per taxpayer), the figure below focuses on the relative difference between each other. The higher value in the positive direction means the greater change in each factor, relative to the average of the 18 settlements.

The graph more highlights the difference among the settlement groups and between the periods. Especially spectacular the case of the first group; its values were lower than the second one's and fourth one's values (except for the tax per taxpayer) at the first period, but the second-highest after 2001. And yet the proportion of incomers in municipal councils was not significant between 1994 and 2014. In contrast, the fourth

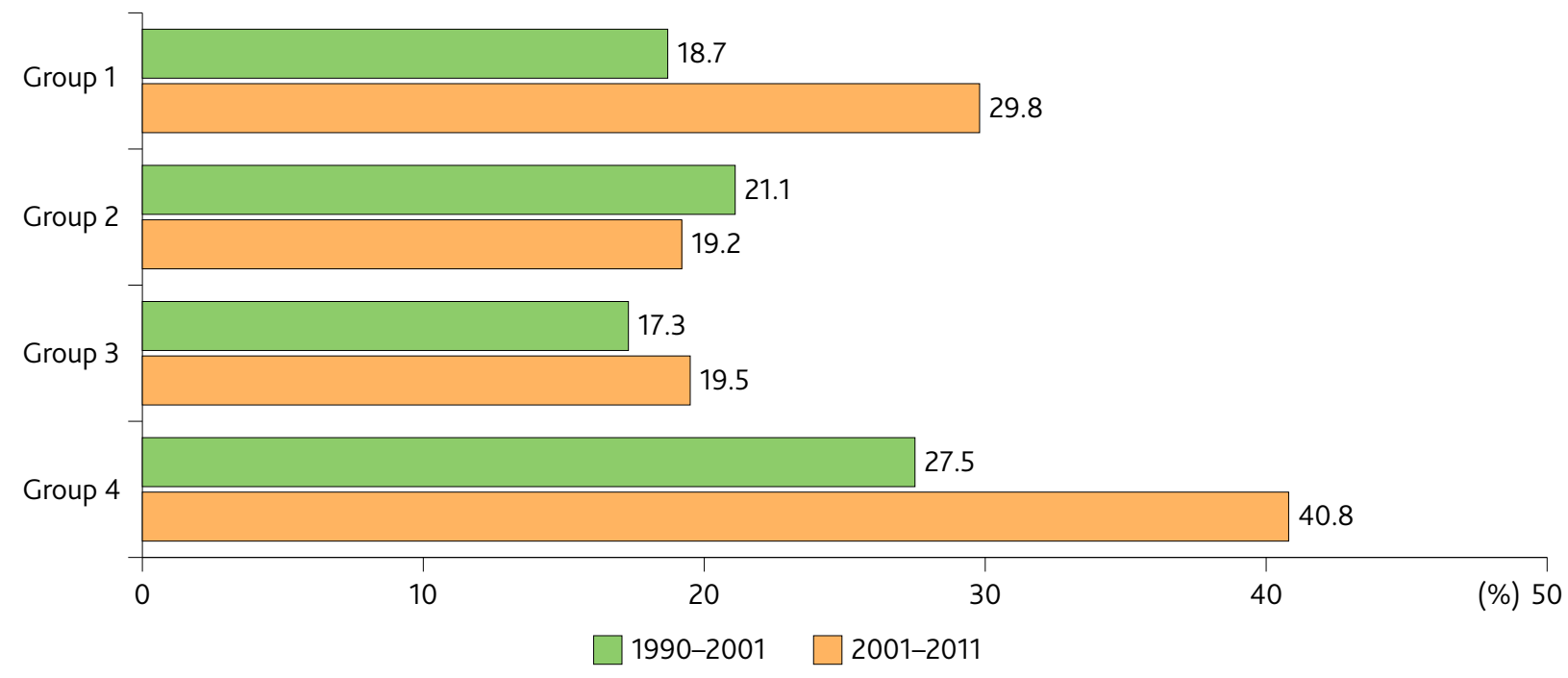

Figure 6. The average proportion of newly built dwellings by settlement groups (\%) Source: Edited by the author based on censuses

this is due to the tax per taxpayer was high in the previous years. In contrast, in the first group the initial rate was low and reached roughly the same level as the third group.

The last social status indicator is the period of dwellings construction that is the proportion of newly built dwellings. As before, the fourth group is considered to be with the highest status, which is not surprising given that the population was in good financial situation. In second and third groups, the proportion of the newly built dwellings was similar. In the first group between 2001 and 2011 was built ten percentage points more dwellings than in the second or the third one even though the average tax per taxpayer was not higher, it refers to a good financial situation in spite of the average income level. group's relative high values can be associated with a high proportion of incomer in councils. Also interesting the situation of the third group; its values were relatively low in each period, and yet the proportion of incomer councillors has been growing.

While four groups can be formed on the basis of the proportion of incomer councillors, the similarities in social-demographic characteristics of settlements show that the second and the third group do not differ from each other considerably. And data do not prove an increasing tendency between the first and fourth group in percentage of incomers. On the contrary, although the population growth and the proportion of newly built dwellings was outstanding, all of this did not result in the high proportion of incomers in municipal councils. 


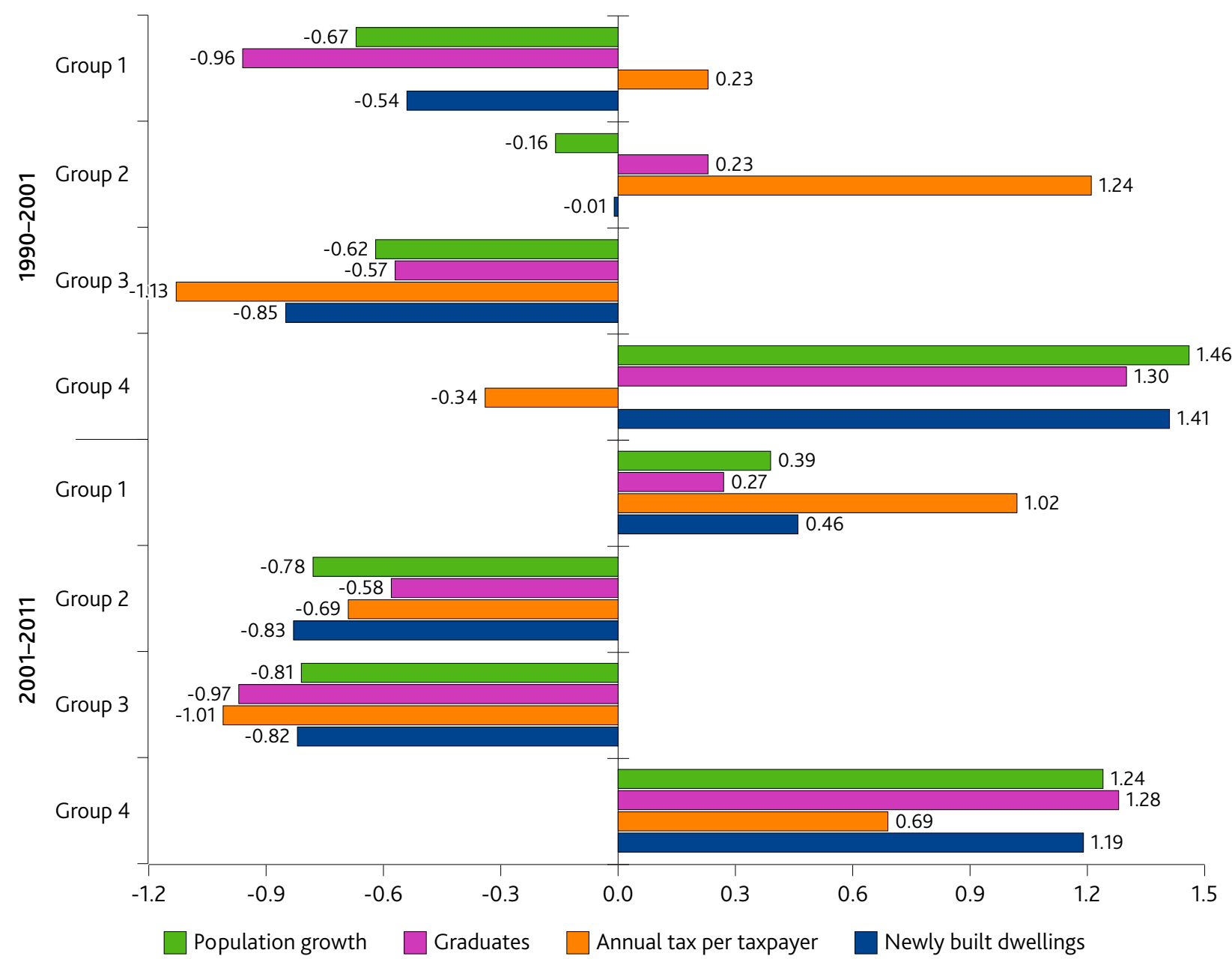

Figure 7. The deviation of socio-demographic characteristics of settlement groups from the average values of the sample settlements by periods Source: Edited by the author based on censuses and TEIR database

\section{Discussion and Conclusion}

The change of municipal councils has been many impacts on the development of Budapest Agglomeration and the socio-spatial fragmentation in local and regional level. In terms of settlement development, it is crucial which population group has the ability to enforce interest. For instance, the answers to the following question can be different: to what extent should the rural character of the settlements remain. From the point of view of society, the process has a role in the spatial distribution of people belonging to different social strata. Set a good example, a village, where the council tried to limit the number of people who move in by regulating the minimum size of building plots, but this regulation favoured people who have a high income.

Results present a remarkable change of composition of municipal councils in Budapest Agglomeration. There are more and more settlements where most councillors are incomers. The data predict that the process will continue (see second and mostly the third group).

The findings from the database show that this process cannot be explained completely by the population change and social-status indicators. In the settlements of the fourth group, there were an outstanding proportion of incomers, and indeed the population growth and the proportion of high-status people was significant. However, results do not present a clear relationship between the explanatory variables and the composition of municipal councils. Especially the values of the first group contradict presumptive relationship as the population growth was significant, the social-status characteristics were similar to the second and third group, and still, the proportion of incomers in councils was negligible.

The results must be interpreted with caution because the selection of settlements was influenced by the available data of councillors. It sets limits on research that the 
personal data about councillors are difficult to collect; thus, not all municipalities could be included in the analysis. The primary importance of the results is not to provide accurate information on the transformation of municipal councils in the studied area, but to highlight the major trends of changes, their complexity, and their relationship to main socio-demographic variables.

And it is important to note again that the sample does not include towns with more than 10 thousand people. Therefore, it may be worthwhile to extend the research to larger towns, although probably some other factors have an effect on the choice of councillors in their case. For instance, the role of political parties can be more significant.

In addition to the official statistical data, it is necessary to do profound research to reveal the demands, conceptions, motives to migration to suburbs, and lifestyle of incomers in the sample area. These factors probably have an influence on local integration intentions and through of these on the endeavour to have a say in the affairs of the settlement. Furthermore, need to examine the significance of local communities and local civil movements on the transformation of municipal councils.

\section{References}

Beluszky, P. (1999). Preliminary comments on the relationship between cities and their agglomeration. In Gy. Barta, \& P. Beluszky (Eds.), Társadalmigazdasági átalakulás a budapesti agglomerációban. [Social-economical transformation in the Budapest agglomeration.] (pp. 225-241). Budapest: Regionális Kutatási Alapítvány.

Brade, I., Herfert, G. \& Wiest, K. (2009). Recent trends and future prospects of socio-spatial differentiation in urban regions of central and eastern Europe: A lull before the storm? Cities, 26(5), 233-244. doi: 10.1016/j.cities.2009.05.001

Csanádi, G., \& Csizmady, A. (2002). Szuburbanizáció és társadalom. [Suburbanisation and society] Tér és Társadalom, 16(3), 27-55. doi: 10.17649/TET.16.3.1978

Csanádi, G., Csizmady A., Kocsis J. B., Köszeghy L., \& Tomay K. (2010). Város, Tervezö, Társadalom. [City, planner, society.] Budapest: Sík Kiadó.

Csizmady A., \& Csurgó B., (2012). A városból vidékre költözők beilleszkedési stratégiái. [Intergartion strategies of people who moved out of the city to the country.] In I. Kovách Imre, Cs. Dupcsik, T. P. Tóth \& J. Takács (Eds.), Társadalmi integráció a jelenkori Magyarországon. Tanulmányok. [Social integration in contemporary Hungary. Studies.] (pp. 133-148). Budapest: Argumentum Kiadó.

Csurgó B. (2013). Vidéken lakni és vidéken élni. A városból vidékre költözők hatása a vidék átalakulására: a város környéki vidék. [Living in the country and residing in the country.] Budapest: Argumentum Kiadó.

Dövényi, Z., \& Kovács Z. (1999). A szuburbanizáció térbeni-társadalmi jellemzői Budapest környékén. [Socio-spatial characteristics of suburbanisation around Budapest.] Földrajzi Értesitöo, 48(1-2), 33-57.

Gergely, J. (2014). Településvezetés és szuburbanizáció. [Local governments and suburbanisation.] Tér és Társadalom, 28(4), 138-55. doi: 10.17649/ TET.28.4.2627
Hungarian Central Statistical Office - HCSO (2001). Közlemények a Budapesti agglomerációról 15. Gyermekvállalás a budapesti agglomerációban 1990- 2009. [Reports of Budapest Agglomeration 15. Willingness to have children in the Budapest Agglomeration 1990-2009.] pp. 32.

Hungarian Central Statistical Office - HCSO (2006): Népesedési folyamatok a budapesti agglomerációban. Közlemények a budapesti agglomerációról. 13. kötet. [Demographic process in Budapest agglomeration. Reports of Budapest agglomeration. 13. Volume] pp. 62.

Hungarian Central Statistical Office - HCSO. (2014). Magyarország településhálózata I. Agglomerációk, településegyüttesek. [Settlement network of Hungary I. Agglomerations.] pp. 256.

Johnson J. R., \& Scicchitano, J. M. (2012). Don't call me NIMBY: Public attitudes toward solid waste facilities. Enviroment and Behavior, 44(3), 410-426. doi: 10.1177/0013916511435354

Kondor, A. (2016). Helyi konfliktusok Budapest szuburbán zónájában. [Local conflicts in the suburban zone of Budapest.] Földrajzi Közlemények, 140(3), 216-228.

Kovács, K. (1999). A szuburbanizációs folyamatok a fövárosban és a budapesti agglomerációban. [Suburbanisation in the Budapest agglomeration] In Gy. Barta, \& P. Beluszky (Eds.), Társadalmi-gazdasági átalakulás a budapesti agglomerációban. [Socialeconomical transformation in the Budapest agglomeration.] (pp. 91-114). Budapest: Regionális Kutatási Alapítvány.

Kovács, Z., Kondor, A. Cs., Szabó, B., \& Harangozó, G. (2019). A budapesti várostérség fogyasztási alapú ökológiai lábnyomának változása 2003 és 2013 között. [Changes in the household consumptiondased ecological footprint of Budapest metropolitan region between 2003 and 2013.] Területi Statisztika, 59(1), 97-123. doi: 10.15196/TS590105 
Kovács, Z., \& Tosics, I. (2014). Urban Sprawl on the Danube. The Impacts of Suburbanization in Budapest. In K. Stanilov, \& L. Sýkora (Eds.), Confronting suburbanization: Urban decentralization in postsocialist Central and Eastern Europe (pp. 33-64). Malden: Wiley Blackwell.

Ourednícek, M. (2007). Differential suburban development in the Prague urban region. Geografiska Annaler Series B Human Geography, 89(2), 111-126. doi: 10.1111/j.1468-0467.2007.00243.x

Ross, B. (2014). Dead End: Suburban Sprawl and the Rebirth of American Urbanism. New York: Oxford University Press.

Sailer-Fliege, U. (1999). Characteristics of post- socialist urban transformation in east central Europe. GeoJournal, 49(1), 7-16.

Schuchmann, J. (2013). Lakóhelyi szuburbanizációs folyamatok a Budapesti agglomerációban. Doktori dolgozat. [Trends of residential suburbanisation in the Budapest agglomeration. Ph.D. Thesis] Széchenyi István University of Győr, Győr.

Solymár (2007): Solymár Nagyközség Településfejlesztési Koncepciója. [Solymár Settlement Development Plan] www.solyamar.hu

Somlyódyné Pfeil, E. (2011). Az agglomerációk jelentőségének változása az államszervezés és a városi kormányzás szempontjából. [The changing significance of agglomerations in light of state spatial organisation and regional governance.] Tér És Társadalom, 25(3), 27-59. doi: 10.17649/TET.25.3.1876

Stanilov, K., \& Sýkora, L. (2014a). Postsocialist suburbanization patterns and dynamics: A comparative perspective. In K. Stanilov, \& L. Sýkora (Eds.), Confronting suburbanization: Urban decentralization in postsocialist Central and Eastern Europe (pp. 256-295). Malden: Wiley Blackwell.

Stanilov, K., \& Sýkora, L. (2014b). Managing suburbanization in postsocialist Europe. In K. Stanilov, \& L. Sýkora (Eds.), Confronting suburbanization: Urban decentralization in postsocialist Central and Eastern Europe (pp. 296-320). Malden: Wiley Blackwell.

Stanilov, K., \& Sýkora, L. (2014c). The challenge of postsocialist suburbanization. In K. Stanilov, \& L. Sýkora (Eds.), Confronting suburbanization: Urban decentralization in postsocialist Central and Eastern Europe (pp. 1-32). Malden: Wiley Blackwell.

Szabó, J. (2003). Települési stratégiák a Budapesti agglomerációban. [Settlements strategies in the Budapest agglomeration.] Tér és Társadalom, 17(4), 101-116. doi: 10.17649/TET.17.4.918

Szabó, T., Szabó B., \& Kovács Z. (2014). Polycentric urban development in post-socialist context: The case of the Budapest metropolitan region. Hungarian Geographical Bulletin, 63(3), 287-301. doi: 10.15201/ hungeobull.63.3.4
Szelényi, I. (1996). Cities under socialism-and after. In G. Andrusz, M. Harloe \& I. Szelényi (Eds.), Cities after socialism: Urban and regional change and conflict in post-socialist societies (pp. 286-317). Oxford: Blackwell Publishers.

Szirmai, V. (2011b). Urban sprawl in Europe: An introduction. In V. Szirmai (Eds.), Urban sprawl in Europe. Similarities or differences? (pp. 13-45). Budapest: AULA Kiadó.

Szirmai, V., Váradi Zs., Kovács, Sz., Baranyai, N., \& Schuchmann, J. (2011). Urban sprawl and its spatial, socail consequences in the Budapest metropolitan region. In V. Szirmai (Eds.), Urban sprawl in Europe. Similarities or differences? (pp. 141-186) Budapest: AULA Kiadó.

Szirmai, V. (2011). A nagyváros szélén: A városi terjeszkedés térbeli társadalmi problémái. [On the edge of a large city: The spatial and social issues of urban sprawl.] Tér És Társadalom, 25(1), 20-41. doi: 10.17649/TET.25.1.1771

Szirmai, V. (2016). Hol Laknak a Magyar Nagyvárosi Térségek Képzett, Illetve Elit Csoportjai? [Where do the qualified and elite groups live in Hungarian metropolitan regions?] In G. Morcsányi, \& G. István (Eds.), A magyar polgár. [The Hungarian citizen.] (pp. 201-214). Budapest: TÁRKI, Magvető.

Szirmai, V. (2019). Városok és városlakók. (A befogadó és kirekesztő városok) [Cities and residents] $\mathrm{Bu}$ dapest: Corvina Kiadó, MTA TK

Tímár,J. (1999). Elméleti kérdéseka szuburbanizációról. [Theoretical questions about suburbanisation] Földrajzi értesítö, 48(1-2), 7-31.

Tosics, I. (2006). Spatial Restructuring in Post-socialist Budapest. In S. Tsenkova, \& Z. Nedovic-Budic (Eds.), The urban mosaic of post-socialist Europe. Space, institutions and policy (pp. 131-150). Physica. doi: 10.1007/3-7908-1727-9.

Váradi, M. M. (1999). Hová megyünk lakni? Szuburbanizációs minták és konfliktusok a budapesti agglomeráció budai oldalán. Esettanulmány. [Where are we going to live? Patterns of suburbanisation and conflict on the left side of Budapest agglomeration. A case study.] In Gy. Barta, \& P. Beluszky (Eds.), Társadalmi-gazdasági átalakulás a budapesti agglomerációban. [Social-economical transformation in the Budapest agglomeration.] (pp. 115-129). Budapest: Regionális Kutatási Alapítvány.

Váradi, Zs., \& Szirmai, V. (2012). Térbeli-társadalmi elkülönülés és integráció a magyar nagyvárostérségekben. [Social-spatial polarisation and cohesion in Hungarian metropolitan eegions] In I. Kovách Imre, Cs. Dupcsik, T. P. Tóth \& J. Takács (Eds.), Társadalmi integráció a jelenkori Magyarországon. Tanulmányok. [Social integration 
in contemporary Hungary. Studies.] (pp. 115-132). Budapest: Argumentum Kiadó.

Váradi, Zs. (2014). Budapest és környéke közötti konfliktusok - együtt vagy külön utakon? [Conflicts between Budapest and its surroundings - Together or in separate ways.] In M. Berki \& L. Halász (Eds.), A társadalom terei, a tér társadalma. Megújulás és fenntarthatóság a város- és térségfejlesztésben. [Spaces of society, society of space. Reformation and sustainability in urban and regional development.] (pp. 217-244). Budapest: Art Webber Studio.
Internet 1: Hungarian Central Statistical Office HCSO. Disseminaion Database http://statinfo.ksh. hu/Statinfo/index.jsp (2018.04.01.)

Internet 2: Hungarian Central Statistical Office HCSO. National Census, 1990 www.ibrary.hungaricana.hu (2018.04.01.)

Internet 3: Hungarian Central Statistical Office HCSO. National Census, 2001 www.nepszamlalas2001.hu (2018.04.01.)

Internet 4: Hungarian Central Statistical Office HCSO. National Census, 2011 www.ksh.hu/nepszamlalas/ (2018.04.01.)

Internet 5: Hungarian Information System of Regional Development - TEIR. https://www.teir.hu (2018.04.01.) 